\title{
Plant Growth, Yield, Macro and Micro-Nutrients Uptake of Fennel (Foeniculum vulgare Mill.) Positively Affected by N-Sources and Rates as well as Foliar Application of Micronutrients
}

\author{
El-Seifi S. K.; M. A. Hassan; M. W. M. Elwan* and O. G. Haggag \\ Department of Horticulture, Faculty of Agriculture, Suez Canal University, Ismailia, Egypt
}

Received: $18 / 2 / 2015$

\begin{abstract}
This study was carried out in order to give some information that could improve fennel nutritional status and productivity. We studied the effect of two $\mathrm{N}$ fertilizers [ammonium nitrate (AN) and ammonium sulphate (AS)], two nitrogen rates (60 and $90 \mathrm{~kg} \mathrm{~N} / \mathrm{fad}$.) and two levels of micronutrients (without and with FeEDTA, MnEDTA and ZnEDTA) on growth, yield and nutrient (N, P, K, Fe, Mn and Zn) uptake on fennel plants cv. Florence. The results indicated that, ammonium sulphate at level of $90 \mathrm{~kg} /$ fad. enhanced plant growth, production of dry matter and improved yield (foliage, bulb and total). Nutritional status of fennel plants was improved, whereas the ammonium sulphate at level of $90 \mathrm{~kg} / \mathrm{fad}$. and spraying of the micronutrient mixture increased the uptake of macronutrients $(\mathrm{N}, \mathrm{P}$ and $\mathrm{K})$ and micronutrients ( $\mathrm{Fe}, \mathrm{Mn}$ and $\mathrm{Zn}$ ). The present study suggests that foliar application of micronutrients could be an effective strategy in bio-fortifying fennel plants with Fe, Mn and $\mathrm{Zn}$ to produce foliage and bulb yield with high nutritional quality.
\end{abstract}

Keywords: Fennel, nitrogen fertilizer, yield, essential elements

\section{INTRODUCTION}

Recently, an increasing interest in the cultivation and production of un-traditional vegetable crops has been noticed in Egypt in order to cover the increasing demand of the local consumption as well as export purposes. Among them sweet fennel (Foeniculum vulgare Mill.) is one of the most promising new crops in Egypt. Also, it is considered as the most important economic medicinal and aromatic plant grown within the Mediterranean region (Kandil et al., 2002).

Mineral fertilizers application is essential for plant growth, development and productivity of plants. Nitrogen is one of the chemical elements required for plant growth and reproduction. It is an essential nutrient which is a determining factor in crop production and it absorbed primarily in the form of nitrate (Tisdale and Nelson, 1990). The dry weight of many crops contain about $1.5-6 \% \mathrm{~N}$ a apart from being a constituent of many organic compounds, nucleic acids and protein compounds (Sanjuan et al., 2003). On the other hand, frequent or excessive amounts of nitrogen fertilizer would lead to un-favorite effect on the growth and yield of plants and will increase the losses of nitrogen fertilizer. So, the adequate amounts of nitrogen fertilization led to improve growth, yield and quality. It is well reported that $\mathrm{N}$ fertilization increased plant growth and yield components of fennel (Hussain and Abo El-Magd, 1993; Ayub et al., 2011; Ehsanipour et al., 2012). On the other hand, other researchers found that application of $\mathrm{N}$ had no marked effect on fennel yield components (Buntain and Chung, 1994; Kandil et al., 2002; Chatzopoulou et al., 2006). There are some supporting studies that $\mathrm{N}$ fertilization affects yield of other medicinal plants (Arabaci and Bayram, 2004; Barreyro et al., 2005; Ashraf et al., 2006; Ozguven et al., 2006; Abbaszadeh et al., 2009; Sotiropoulou and Karamanos, 2010; Jabbari et al., 2011). In crops whose commercial yields are the leaves, such as lettuce, spinach, endive, cabbage, etc., a great number of studies have been done on the influence of $\mathrm{N}$ fertilization (rate and form) on yield and ion composition (Wang and Tadashi, 1997; Santamaria and Elia, 1997; Simonne et al., 2001; Wang and Li, 2004).

Iron $(\mathrm{Fe})$ is a cofactor for approximately 140 enzymes that catalyze unique biochemical reactions (Brittenham, 1994). Hence, iron fills many essential roles in plant growth and development, including chlorophyll synthesis, thylakoid synthesis and chloroplast development (Miller et al., 1995). Iron is required at several steps in the biosynthetic pathways. Zinc $(\mathrm{Zn})$ is an essential element for plant that act as a metal component of various enzymes or as a functional structural or regulatory cofactor and for protein synthesis, photosynthesis, the synthesis of auxin, cell division, the maintenance of membrane structure and function, and sexual fertilization (Marschner, 1995). Manganese also is a micronutrient plays important role in life cycle of the plant. It involved in the oxygenevolving step of photosynthesis and membrane function, as well as serving as an important activator of numerous enzymes in the cell (Wiedenhoeft, 2006).

Said-Al Ahl and Mahmoud (2011) found that the addition of micronutrients had an active effect comparing with control on sweet basil (Ocimum basilicum L.). Results of Jabbari et al. (2011) showed that the application of iron had a suppressing effect on the vegetative yield of thyme. Mineral elements like $\mathrm{Zn}$ and $\mathrm{Fe}$ are as crucial for human health as organic compounds such as carbohydrates, fats, protein and vitamins.

It is clear that micronutrients plays a positive role in plant growth and yield, however, little information has been reported about the role of micronutrients in $\mathrm{N}$ nutrition of vegetable crops (Assimakopoulou, 2006) and no literature was found on the role of micronutrients in N-nutrition of fennel. Therefore, the main objectives of the current proposed study are: Firstly to assess the effect of nitrogen source and rates on growth, yield and chemical analysis of fennel cv. Florence. Secondly to 
determine the effect of foliar application of micronutrients, such as iron, zinc and manganese on the efficiency of nitrogen fertilizer for enhancing growth, yield, macro-nutrients and micro-nutrients uptake by fennel plants cv. Florence.

\section{MATERIALS AND METHODS}

Two field experiments were carried out at the Experimental Research Farm, Faculty of Agriculture, Suez Canal University, Ismailia Governorate, Egypt, during the two successive winter seasons of 2012-2013 and 2013-2014. The experiments were designed to investigate the effects of nitrogen sources, nitrogen levels, spraying of micronutrients and their interactions on plant growth, yield and macro and micronutrients concentration in fennel plants (Foeniculum vulgare Mill.) cv. Florence.

Random soil samples were collected from 0.0 $50.0 \mathrm{~cm}$ depth, before each plantation and homogenized together to determine the physicochemical characteristics of air-dried, crushed and sieved $(<2 \mathrm{~mm})$ soil in accordance to the methods of Gee and Bauder (1986) and Sparks et al. (1996). Soluble cations $\mathrm{Na}^{+}$, $\mathrm{K}^{+}, \mathrm{Ca}^{2+}$ and $\mathrm{Mg}^{2+}$ and anions $\mathrm{HCO}_{3}^{-}$and $\mathrm{Cl}^{-}$were determined in the soil solution (Richards, 1954). Sulfate $\left(\mathrm{SO}_{4}{ }^{2-}\right)$ was precipitated by barium chloride as barium sulfate and gravimetrically determined (Jackson, 1967). Electrical conductivity of the saturated soil paste extract expressed as $\mathrm{dSm}^{-1}$ was measured using a conductivity meter model Jenway 3310 (Jenway Ltd., Essex, Cambridge, UK) according to Richards (1954). Soil pH was determined by bench type Beckman glass electrode $\mathrm{pH}$ meter, in 1: 2.5 soil-water suspensions according to Page et al. (1982). The soil of the experimental site was sandy soil (85.21\% sand, $11.5 \%$ silt and $3.29 \%$ clay) with $\mathrm{pH} 8.27$, electrical conductivity (EC) $0.47 \mathrm{dSm}^{-1}$, calcium (Ca) $0.4 \mathrm{mM}$, magnesium $(\mathrm{Mg}) \quad 0.3 \mathrm{mM}$, potassium $(\mathrm{K}) \quad 0.3 \mathrm{mM}, \mathrm{Na} 3.0 \mathrm{mM}$, bicarbonate $\left(\mathrm{HCO}_{3}\right) 1.6 \mathrm{mM}$, chloride $(\mathrm{Cl}) 3.0 \mathrm{mM}$, and sulfate $\left(\mathrm{SO}_{4}\right) 0.05 \mathrm{mM}$. Available inorganic soil N (4.10 $\mathrm{mgkg}^{-1}$ soil) was extracted using $2.0 \mathrm{M}$ potassium chloride and determined according to the Kjeldaha method (Bremner, 1996). The available inorganic $P$ (10.32 $\mathrm{mgkg}^{-1}$ soil) was determined by the spectrophotometer (Jenway $6105)$ in $0.5 \mathrm{M} \mathrm{NaHCO}_{3}$-soil extract according to the Olsen method (Kuo, 1996). The available micronutrients (Fe; $0.78 \mathrm{mg} \mathrm{kg}^{-1}$ soil, $\mathrm{Mn} ; 0.63 \mathrm{mg} \mathrm{kg}^{-1}$ soil and $\mathrm{Zn}$; $0.36 \mathrm{mg} \mathrm{kg}^{-1}$ soil) were determined using the atomic absorption spectrophotometer (Thermoelectron, Series GE711838) in diethylene triaminepentaacetic acid (DTPA) extract. Before planting, the experimental location was prepared. During preparation the soil of the site was cleared, ploughed, harrowed and divided into plots.

The experiments were laid-out in a split split-plot in randomized complete block design with three replicates. Experiment was subjected to combinations of two nitrogen sources (ammonium nitrate $33.5 \%$ and ammonium sulphate $20.5 \%$ ), two nitrogen rates (60 and $90 \mathrm{k} \mathrm{N} / \mathrm{fad}$.) and two concentrations of micronutrients mixtures (without and with). Nitrogen was added at rates of 60 and $90 \mathrm{k} \mathrm{N} /$ fad., which equivalent to about
180 and $270 \mathrm{~kg}$ ammonium nitrate or 300 and $450 \mathrm{~kg}$ ammonium sulphate per faddan, respectively. The micronutrients mixtures containing Fe-EDTA 13.5\% (one g/l) + Mn-EDTA 13\% (0.5 g/l) + Zn-EDTA 14\% $(0.5 \mathrm{~g} / \mathrm{l})$ after dissolving in water (separately) and mixed before spraying. The volume of sprayed solution ranged from $1 \mathrm{~L}$ to $2 \mathrm{~L}$ per plot each time, depending on plant developmental stage. The same amount of water was sprayed to the control plants. The sprays in all cases were carried out with a manual pump in the morning.

Seeds of fennel cv. Florence were sown in nursery of the Horticulture Department, Faculty of Agriculture for seven weeks staring from August $28^{\text {th }}$, in the first season and from September $10^{\text {th }}$, in the second season. After emergence, the fennel seedlings received the normal agriculture practices.

Plot area was one row $(25 \mathrm{~m}$ in length and $1.0 \mathrm{~m}$ in width) containing about 83 plants at a spacing of $0.3 \mathrm{~m}$ within the row. The environmental conditions were as follows: a 10-12 $\mathrm{h}$ photoperiod, day temperature fluctuated between $4-25^{\circ} \mathrm{C}$ and $15-35{ }^{\circ} \mathrm{C}$ for minimum and maximum temperature, respectively. Relative humidity ranged from $15 \%$ to $47 \%$ and from $74-90 \%$ for minimum and maximum relative humidity, respectively.

Fennel nurslings, seven weeks old were transplanted on October $15^{\text {th }}$ and October $29^{\text {th }} 2013$ for 2012 and 2013 seasons, respectively. Nitrogen fertilizer levels were added at four equal doses 3, 6, 9 and 12 weeks after transplanting. Each plant received a total of 4.5 or $6.75 \mathrm{~g}$ ammonium nitrate or 7.5 or $11.25 \mathrm{~g}$ ammonium sulphate (60 and $90 \mathrm{k} \mathrm{N} /$ fad.) in both seasons. Mixture of micronutrients applied foliarly four times during growing seasons and added in the same time of nitrogen fertilizer addition. The soil moisture content was kept at an appropriate $(50-75 \%)$ of field capacity for sandy soil as described by Klocke and Fischbach (1984) and Miles and Broner (1998). Recommended practices for disease and insect pests control were followed.

\section{Data collection and analysis Plant biomass}

Leaf and bulb fresh weights of five plants for each replicate were determined using gravimetric method. Dry weight of leaves and bulbs were determined after oven drying at $70^{\circ} \mathrm{C}$ up to constant weight.

\section{Yield}

At marketable stage (after three and half months), all sweet fennel plants from each sub sub-plot were harvested to record total foliage yield expressed as ton/fad. Bulbs were excised by cutting $5 \mathrm{~cm}$ above the bulb using a sharp stainless steel knife. Also, roots were excised and the outer-leaf removed for obtaining clean bulbs for each sub sub-plot to record total bulb yield expressed as ton/fad.

\section{Analysis of macro and micro-nutrients}

$0.5 \mathrm{~g}$ of powdered materials (leaves and bulbs) was digested separately for each plants (three samples per replicate) using a mixture of sulfuric acid and hydrogen peroxide and then brought to a final volume of $50 \mathrm{ml}$ with distilled water. Total nitrogen was estimated using 
semi-micro-kjeldahl method as described by Ling (1963). Phosphorus was analyzed by a vanadatemolybdate method at $660 \mathrm{~nm}$ using a Spectro 22 spectrophotometer (Chapman and Pratt, 1982). Potassium was determined using a Perkin-elmer, Flame photometer (Page, 1982). Fe, Mn and $\mathrm{Zn}$ were determined using the Atomic Absorption Spectrophotometer (Perkin-Elmer 100B).

\section{Statistical analysis:}

The results were evaluated using descriptive statistics and analysis of variance (ANOVA). Using two-way ANOVA, the effect of nitrogen sources, nitrogen levels and micronutrients foliar application as well as their interactions were evaluated by Fisher's Ftest, followed by Duncan's multiple range test for comparing the main effects means and the eight NS $\mathrm{x}$ NR x MX combinations. All tests were performed at a significance level $\alpha$ of 0.05 . Calculations were carried out using the software package Statistica $^{\mathrm{TM}}$ for Windows version 6.1 (Statsoft Inc., 2001, Tulsa, Oklahoma, USA).

\section{RESULTS}

The main effects of nitrogen source, nitrogen rates, application of micronutrients as well as their triple interaction on leaf fresh weight, bulb fresh weight and total foliage fresh weight of fennel plants cv. Florence are presented in Table (1). The obtained results indicate that the fennel plants fertilized with ammonium sulphate had, in most cases, the highest leaf fresh weight, bulb fresh weight and total foliage fresh weight of fennel plants in both seasons. Regarding to the main effect of nitrogen level, the results prove that the leaf fresh weight, bulb fresh weight and total foliage fresh weight of fennel plants were significantly increased by increasing nitrogen level from $60 \mathrm{~kg} /$ fad to $90 \mathrm{~kg} / \mathrm{fad}$. a rate of $90 \mathrm{~kg} / \mathrm{fad}$. or ammonium sulphate at both tested levels (60 or $90 \mathrm{~kg} /$ fad.) combined with sprayed or nonsprayed plants with micronutrients in the first season. However, in the second season the higher bulb fresh weight were found in plants treated with ammonium nitrate at the high level (90 kg/fad.) or ammonium sulphate at both tested levels Mostly, spraying fennel plants with mixture of micronutrients significantly improved leaf, bulb and total plant fresh weight (Table $1)$.

Regarding to the triple interaction effects, results show that the highest leaf fresh weight in fennel plants was observed when plants fertilized with ammonium sulphate at higher level $(90 \mathrm{~kg} / \mathrm{fad}$.) and sprayed with the mixture of micronutrients with no significant difference when compared with those fertilized with 90 $\mathrm{kg} \mathrm{N} / \mathrm{fad}$. ammonium nitrate combined with micronutrients mixture in both seasons. The higher bulb fresh weight were found in plants supplied with ammonium nitrate at (60 or $90 \mathrm{~kg} / \mathrm{fad}$.) combined with spraying with micronutrients (Table 1). Regarding to total plant fresh weight, the results showed that fennel plants cv. Florence fertilized with ammonium sulphate as $\mathrm{N}$-source at high level $(90 \mathrm{~kg} / \mathrm{fad})$ and micronutrients gave higher total plant fresh weight in both seasons. It is clear also that, the most favorable interaction treatments for increasing total plant fresh weight were fertilizing fennel plants with $90 \mathrm{~kg} \mathrm{~N} /$ fad from either Anitrate or A-sulphate combined with micronutrients with no significant differences between them in both seasons of study (Table 1).

The results of the main effects of nitrogen source, nitrogen rate and spying with micronutrients showed that fennel plants fertilized with ammonium sulphate, higher $\mathrm{N}$ rate $(90 \mathrm{~kg} / \mathrm{fad}$.) and sprayed with mixture of micronutrients significantly recorded the highest values of leaf, bulb and total plant dry weight in comparison with ammonium nitrate as nitrogen source (Table 2). The results of the triple interaction effect reveal that the fennel plants fertilized with the highest added rate of ammonium sulphate ( $90 \mathrm{~kg} \mathrm{~N} / \mathrm{fad}$.) and supplemented with the mixture of micronutrients gave the significant highest leaf, bulb and total plant dry weight, followed by ammonium sulphate at $90 \mathrm{~kg} \mathrm{~N} / \mathrm{fad}$. without micronutrients then $60 \mathrm{~kg} \mathrm{~N} /$ fad. ammonium sulphate with micronutrients. These last two treatments did not differ significantly when compared with $60 \mathrm{~kg} \mathrm{~N} / \mathrm{fad}$. as ammonium nitrate regarding leaf dry weight and total dry weight of fennel plants (Table 2).

The main effect of nitrogen source affected significantly the yield parameters, in most cases, whereas ammonium sulfate improved significantly leaf yield, bulb yield and total plant yield in comparison with ammonium nitrate as $\mathrm{N}$-source, except leaf yield and total yield per fad. in the second season which did not show any significantly differences between both nitrogen source (Table 3). Regarding the effect of nitrogen rate, the results indicate that the leaf, bulb and total plant yield increased markedly with increasing nitrogen rate from 60 to $90 \mathrm{~kg} / \mathrm{fad}$ in both seasons (Table 3). Generally, the data concerning the main effect of spraying of plants with micronutrient reveal that the fennel plants received mixture of micronutrients produced the highest leaf, bulb and total yield of fennel and this effect was significant in both seasons, except bulb and total yield in the first season which did not significantly differed (Table 3 ).

The results regarding triple interaction among ammonium sulphate, high level of nitrogen $(90 \mathrm{~kg}$ $\mathrm{N} /$ fad.) and the foliar spraying with mixture of micronutrients (Fe, $\mathrm{Mn}$ and $\mathrm{Zn}$ ) gave non-significant highest yield components of fennel plants cv. Florence (Table 3). The results showed also that this favorable effect of the previous interaction was not differed significantly when ammonium nitrate was used instead of ammonium sulfate (Table 3) as N-source in combination with high nitrogen level and spraying with micronutrients.

Results of the influence of nitrogen source and rate in addition to foliar application of micronutrients as well as their interactions on the uptake of macro $(\mathrm{N}, \mathrm{P}$ and $\mathrm{K}$ ) and micro-nutrients (Fe, Mn and $\mathrm{Zn}$ ) by fennel cv. Florence were evident in Tables (4 and 5). The results of the main effect of nitrogen source and rate showed that fennel plants fertilized with ammonium sulphate and higher nitrogen rate $(90 \mathrm{~kg} / \mathrm{fad}$.) significantly increased, in most cases, the uptake of 
macro and micro-nutrients in different plant parts (leaf and bulb) in comparison with ammonium nitrate as nitrogen source. Also, the fennel plants sprayed with mixture of micronutrients (Fe, $\mathrm{Mn}$ and $\mathrm{Zn}$ ) had the significant higher macro and micro-nutrients uptake by different fennel plant parts (Table 4 and 5). The results of triple interaction revealed that the fennel plants fertilized with high level of ammonium sulphate and sprayed with the micronutrients mixtures gave the significant highest nitrogen, phosphorus and potassium uptake (mg/plant), except only ammonium nitrate at low level $(60 \mathrm{~kg} \mathrm{~N} /$ fad.) and spraying plants with micronutrients mixtures gave the significant highest bulb nitrogen uptake (Table 4). Also, in the same direction, the fennel fertilized-plants with high level of ammonium sulphate and sprayed with the micronutrients mixtures gave the significant highest iron, manganese and zinc uptake (mg/plant) as presented in Table (5).

\section{DISCUSSION}

Nitrogen source, N-rate, application of micronutrients and their interactions significantly influenced plant growth (Table 1 and 2), yield (Table 3) and elements uptake (Tables 4 and 5) of fennel plants cv. Florence. Mostly, the highest plant growth, yield and elements uptake were associated with the fennel plants fertilized with ammonium sulphate in comparison with ammonium nitrate as $\mathrm{N}$-source. These results were supported by the previous results of Elwan and Abd ElHamed (2011) who found that ammonium sulphate produced higher plant growth and yield of broccoli in comparison with other $\mathrm{N}$-sources such as ammonium nitrate and urea. The positive effect of ammonium sulphate (contain $24 \%$ sulfur) on yield may be explained by the fact that ammonium sulphate as $\mathrm{N}$-form decrease soil $\mathrm{pH}$, which might favor the elements availability and uptake by plants in slightly alkaline soils (Guelser, 2005; Fageria et al., 2010). From our results of this investigation, the results presented in Tables (4 and 5) showed that the uptake of macronutrients $(\mathrm{N}, \mathrm{P}$ and $\mathrm{K})$ and micronutrients ( $\mathrm{Fe}, \mathrm{Mn}$ and $\mathrm{Zn}$ ) were significantly higher in fennel plants fertilized with ammonium sulphate compared to ammonium nitrate. These results confirmed the fact that ammonium sulphate as $\mathrm{N}$-source decrease soil $\mathrm{pH}$ and increase the elements availability and uptake in slightly alkaline soils as in our study where the experimental soil $\mathrm{pH}$ was 8.27.

Table (1): Main and triple interaction effects of nitrogen source and levels in addition to foliar application of micronutrients on fresh weight of vegetative growth, bulb and total plant of fennel cv. "Florence" during 2012/2013 and 2013/2014 seasons.

\begin{tabular}{|c|c|c|c|c|c|c|c|c|}
\hline \multirow{2}{*}{ N-Source } & \multirow{2}{*}{$\begin{array}{c}\text { N-Rate } \\
\text { (Kg/fad) }\end{array}$} & \multirow{2}{*}{ Micronutr. Mix. } & \multicolumn{2}{|c|}{ Leaf FW (g/plant) } & \multicolumn{2}{|c|}{ Bulb FW (g/plant) } & \multicolumn{2}{|c|}{ Total Plant FW (g/plant) } \\
\hline & & & 2012-2013 & 2013-2014 & 2012-2013 & 2013-2014 & 2012-2013 & 2013-2014 \\
\hline A-Nitr. & & & $141.40 b^{*}$ & $316.46 \mathrm{a}$ & $43.80 \mathrm{~b}$ & $95.05 \mathrm{~b}$ & $185.20 \mathrm{~b}$ & $411.51 \mathrm{a}$ \\
\hline \multirow[t]{5}{*}{ A-Sulf. } & & & $158.90 \mathrm{a}$ & $306.31 \mathrm{a}$ & $50.92 \mathrm{a}$ & $116.77 \mathrm{a}$ & $209.82 \mathrm{a}$ & $423.08 \mathrm{a}$ \\
\hline & 60 & & $125.01 \mathrm{~b}$ & $288.23 \mathrm{~b}$ & $41.68 \mathrm{~b}$ & $97.40 \mathrm{~b}$ & $166.69 \mathrm{~b}$ & $385.63 \mathrm{~b}$ \\
\hline & 90 & & $175.29 \mathrm{a}$ & $334.55 \mathrm{a}$ & $53.04 \mathrm{a}$ & $114.41 \mathrm{a}$ & $228.33 \mathrm{a}$ & $448.96 \mathrm{a}$ \\
\hline & & - & $142.27 \mathrm{~b}$ & $276.43 \mathrm{~b}$ & $47.21 \mathrm{a}$ & $93.62 \mathrm{~b}$ & $189.47 \mathrm{a}$ & $370.06 \mathrm{~b}$ \\
\hline & & + & $158.03 \mathrm{a}$ & $346.34 \mathrm{a}$ & $47.52 \mathrm{a}$ & $118.19 \mathrm{a}$ & $205.55 \mathrm{a}$ & $464.53 \mathrm{a}$ \\
\hline \multirow{4}{*}{ A-Nitr. } & & - & $104.83 \mathrm{~d}$ & $247.88 \mathrm{bc}$ & $31.60 \mathrm{~b}$ & $88.93 \mathrm{~d}$ & $136.43 \mathrm{~d}$ & $336.82 \mathrm{~cd}$ \\
\hline & & + & $104.11 \mathrm{~d}$ & $365.08 \mathrm{a}$ & $35.40 \mathrm{~b}$ & $97.02 \mathrm{~cd}$ & $139.51 \mathrm{~d}$ & $462.10 \mathrm{ab}$ \\
\hline & & - & $177.18 \mathrm{ab}$ & $299.90 \mathrm{~b}$ & $56.95 \mathrm{a}$ & $86.17 \mathrm{~d}$ & $234.13 \mathrm{ab}$ & $386.07 \mathrm{bc}$ \\
\hline & ני & + & $179.48 \mathrm{ab}$ & $389.50 \mathrm{a}$ & $51.24 \mathrm{a}$ & $121.10 \mathrm{ab}$ & $230.72 \mathrm{abc}$ & $510.60 \mathrm{a}$ \\
\hline \multirow{4}{*}{ A-Sulf. } & & - & $138.09 \mathrm{c}$ & $224.83 \mathrm{c}$ & $53.11 \mathrm{a}$ & $75.50 \mathrm{~d}$ & $191.20 \mathrm{c}$ & $300.33 \mathrm{~d}$ \\
\hline & & + & $153.00 \mathrm{bc}$ & $283.42 \mathrm{~b}$ & $46.61 \mathrm{a}$ & $117.20 \mathrm{ab}$ & $199.61 \mathrm{bc}$ & $400.62 \mathrm{bc}$ \\
\hline & & - & $148.97 \mathrm{bc}$ & $307.32 \mathrm{~b}$ & $47.16 \mathrm{a}$ & $114.83 \mathrm{bc}$ & $196.13 \mathrm{bc}$ & $422.15 \mathrm{~b}$ \\
\hline & & + & $195.54 \mathrm{a}$ & $368.95 \mathrm{a}$ & $56.81 \mathrm{a}$ & $138.90 \mathrm{a}$ & $252.35 \mathrm{a}$ & $507.85 \mathrm{a}$ \\
\hline
\end{tabular}

*Values followed by the same letter within a column are not significantly different at the $0.05 \%$ level of probability according to Duncan's multiple range test. A. Nitr.=Ammonium nitrate; A. Sulf.= Ammonium Sulfate; Micronutr. Mix.= Micronutrients Mixture 
Table (2): Main and triple interaction effects of nitrogen source and levels in addition to foliar application of micronutrients on dry weight of vegetative growth, bulb and total plant in fennel cv. "Florence" during 2013/2014 season.

\begin{tabular}{|c|c|c|c|c|c|}
\hline N-Source & $\begin{array}{l}\text { N-Rate } \\
\text { (Kg/fad) }\end{array}$ & Micronutr. Mix. & Leaf DW (g/plant) & Bulb DW (g/plant) & Total Plant DW (g/plant) \\
\hline A-Nitr. & & & $37.95 b^{*}$ & $10.28 \mathrm{~b}$ & $48.21 \mathrm{~b}$ \\
\hline \multirow[t]{5}{*}{ A-Sulf. } & & & $42.26 \mathrm{a}$ & $13.86 \mathrm{a}$ & $56.11 \mathrm{a}$ \\
\hline & 60 & & $38.63 \mathrm{~b}$ & $11.01 \mathrm{~b}$ & $49.64 \mathrm{~b}$ \\
\hline & 90 & & $41.56 \mathrm{a}$ & $13.13 \mathrm{a}$ & $54.69 \mathrm{a}$ \\
\hline & & - & $35.59 \mathrm{~b}$ & $10.90 \mathrm{~b}$ & $46.48 \mathrm{~b}$ \\
\hline & & + & $44.61 \mathrm{a}$ & $13.24 \mathrm{a}$ & $57.85 \mathrm{a}$ \\
\hline \multirow{4}{*}{ A-Nitr. } & \multirow{2}{*}{60} & - & $31.95 \mathrm{~d}$ & $10.00 \mathrm{~cd}$ & $41.95 \mathrm{e}$ \\
\hline & & + & $45.88 \mathrm{ab}$ & $10.50 \mathrm{c}$ & $56.38 \mathrm{~b}$ \\
\hline & \multirow{2}{*}{90} & - & $36.02 \mathrm{~cd}$ & $9.93 \mathrm{~cd}$ & $45.95 \mathrm{de}$ \\
\hline & & + & $37.83 \mathrm{c}$ & $11.10 \mathrm{c}$ & $48.93 \mathrm{~cd}$ \\
\hline \multirow{4}{*}{ A-Sulf. } & \multirow{2}{*}{60} & - & $30.87 \mathrm{~d}$ & $8.23 \mathrm{~d}$ & $39.10 \mathrm{e}$ \\
\hline & & + & $41.95 \mathrm{bc}$ & $13.92 \mathrm{~b}$ & $55.87 \mathrm{bc}$ \\
\hline & \multirow{2}{*}{90} & - & $41.15 \mathrm{bc}$ & $14.08 \mathrm{~b}$ & $55.23 \mathrm{bc}$ \\
\hline & & + & $49.37 \mathrm{a}$ & $16.38 \mathrm{a}$ & $65.75 \mathrm{a}$ \\
\hline
\end{tabular}

*Values followed by the same letter within a column are not significantly different at the $0.05 \%$ level of probability according to Duncan's multiple range test. A. Nitr.=Ammonium nitrate; A. Sulf.= Ammonium Sulfate; Micronutr. Mix.= Micronutrients Mixture

Table (3): Main and triple interaction effects of nitrogen source and levels in addition to foliar application of micronutrients on yield of fennel cv. "Florence" during 2012/2013 and 2013/2014 seasons.

\section{N-Source $\begin{gathered}\text { N-Rate } \\ (\text { Kg/fad })\end{gathered}$ Micronutr. Mix.}

Foliage Yield (ton/fad.) Bulb Yield (ton/fad.) Total Yield (ton/fad.)

$2012-2013 \quad 2013-2014 \quad 2012-2013 \quad 2013-2014 \quad 2012-2013 \quad 2013-2014$

\begin{tabular}{|c|c|c|c|c|c|c|c|c|}
\hline A-Nitr. & & & $1.98 b^{*}$ & $4.43 \mathrm{a}$ & $0.613 b$ & $1.33 \mathrm{~b}$ & $2.59 \mathrm{~b}$ & $5.76 \mathrm{a}$ \\
\hline \multirow[t]{5}{*}{ A-Sulf. } & & & $2.22 \mathrm{a}$ & $4.29 \mathrm{a}$ & $0.713 \mathrm{a}$ & $1.63 \mathrm{a}$ & $2.94 \mathrm{a}$ & $5.92 \mathrm{a}$ \\
\hline & \multicolumn{2}{|l|}{60} & $1.75 \mathrm{~b}$ & $4.04 \mathrm{~b}$ & $0.584 \mathrm{~b}$ & $1.36 \mathrm{~b}$ & $2.33 \mathrm{~b}$ & $5.40 \mathrm{~b}$ \\
\hline & \multirow[t]{3}{*}{90} & & $2.45 \mathrm{a}$ & $4.68 \mathrm{a}$ & $0.743 \mathrm{a}$ & $1.60 \mathrm{a}$ & $3.20 \mathrm{a}$ & $6.29 \mathrm{a}$ \\
\hline & & - & $1.99 \mathrm{~b}$ & $3.87 \mathrm{~b}$ & $0.661 \mathrm{a}$ & $1.31 \mathrm{~b}$ & $2.65 \mathrm{a}$ & $5.18 \mathrm{~b}$ \\
\hline & & + & $2.21 \mathrm{a}$ & $4.85 \mathrm{a}$ & $0.665 \mathrm{a}$ & $1.65 \mathrm{a}$ & $2.88 \mathrm{a}$ & $6.50 \mathrm{a}$ \\
\hline \multirow{4}{*}{ A-Nitr. } & \multirow{2}{*}{60} & - & $1.47 \mathrm{~d}$ & $3.47 \mathrm{c}$ & $0.442 \mathrm{~b}$ & $1.25 \mathrm{c}$ & $1.91 \mathrm{~d}$ & $4.72 \mathrm{~cd}$ \\
\hline & & + & $1.46 \mathrm{~d}$ & $5.12 \mathrm{a}$ & $0.496 \mathrm{~b}$ & $1.35 \mathrm{c}$ & $1.95 \mathrm{~d}$ & $6.47 \mathrm{ab}$ \\
\hline & \multirow{2}{*}{90} & - & $2.48 \mathrm{ab}$ & $4.20 \mathrm{~b}$ & $0.796 \mathrm{a}$ & $1.21 \mathrm{~cd}$ & $3.28 \mathrm{ab}$ & $5.45 \mathrm{bcd}$ \\
\hline & & + & $2.51 \mathrm{ab}$ & $5.45 \mathrm{a}$ & $0.717 \mathrm{a}$ & $1.70 \mathrm{~b}$ & $3.23 \mathrm{abc}$ & $7.15 \mathrm{a}$ \\
\hline \multirow{4}{*}{ A-Sulf. } & \multirow{2}{*}{60} & - & $1.93 \mathrm{c}$ & $3.15 \mathrm{c}$ & $0.744 \mathrm{a}$ & $1.06 \mathrm{~d}$ & $2.68 \mathrm{c}$ & $4.20 \mathrm{~d}$ \\
\hline & & + & $2.14 \mathrm{bc}$ & $3.97 \mathrm{~b}$ & $0.652 \mathrm{a}$ & $1.64 \mathrm{~b}$ & $2.79 \mathrm{bc}$ & $5.61 \mathrm{bc}$ \\
\hline & \multirow{2}{*}{90} & - & $2.09 \mathrm{bc}$ & $4.30 \mathrm{~b}$ & $0.660 \mathrm{a}$ & $1.61 \mathrm{~b}$ & $2.75 b c$ & $5.91 \mathrm{ab}$ \\
\hline & & + & $2.74 \mathrm{a}$ & $5.16 \mathrm{a}$ & $0.795 \mathrm{a}$ & $1.95 \mathrm{a}$ & $3.53 \mathrm{a}$ & $7.11 \mathrm{a}$ \\
\hline
\end{tabular}

*Values followed by the same letter within a column are not significantly different at the $0.05 \%$ level of probability according to Duncan's multiple range test. A. Nitr.=Ammonium nitrate; A. Sulf.= Ammonium Sulfate; Micronutr. Mix.= Micronutrients Mixture 
Table (4): Main and triple interaction effects of nitrogen source and levels in addition to foliar application of micronutrients on the uptake of nitrogen, phosphorus and potassium of fennel cv. "Florence" during 2013/2014 season.

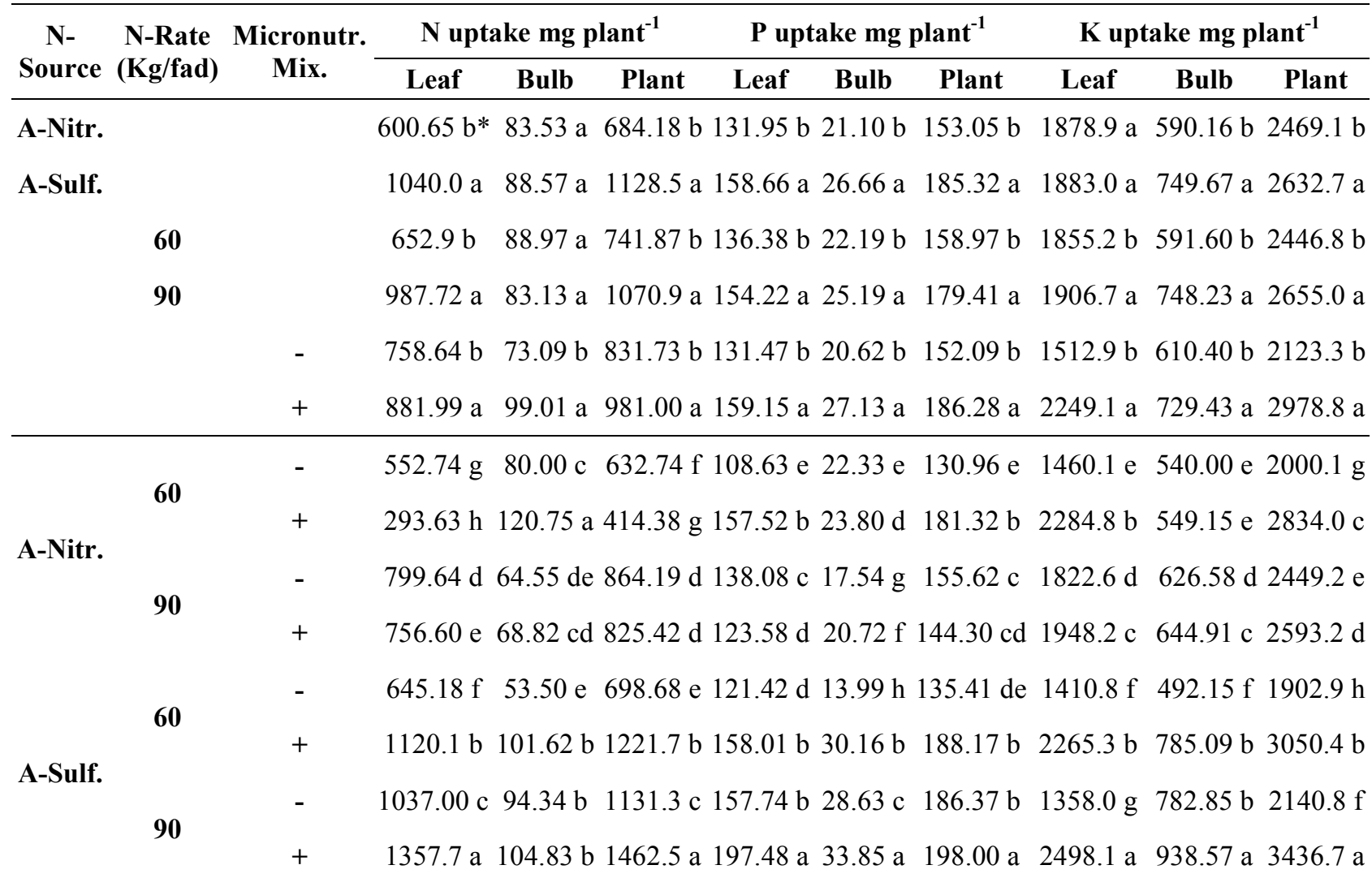

*Values followed by the same letter within a column are not significantly different at the $0.05 \%$ level of probability according to Duncan's multiple range test. A. Nitr.=Ammonium nitrate; A. Sulf.= Ammonium Sulfate; Micronutr. Mix.= Micronutrients Mixture

Table (5): Main and triple interaction effects of nitrogen source and levels in addition to foliar application of micronutrients on the content of iron, manganese and zinc of fennel cv. "Florence" during 2013/2014 season.

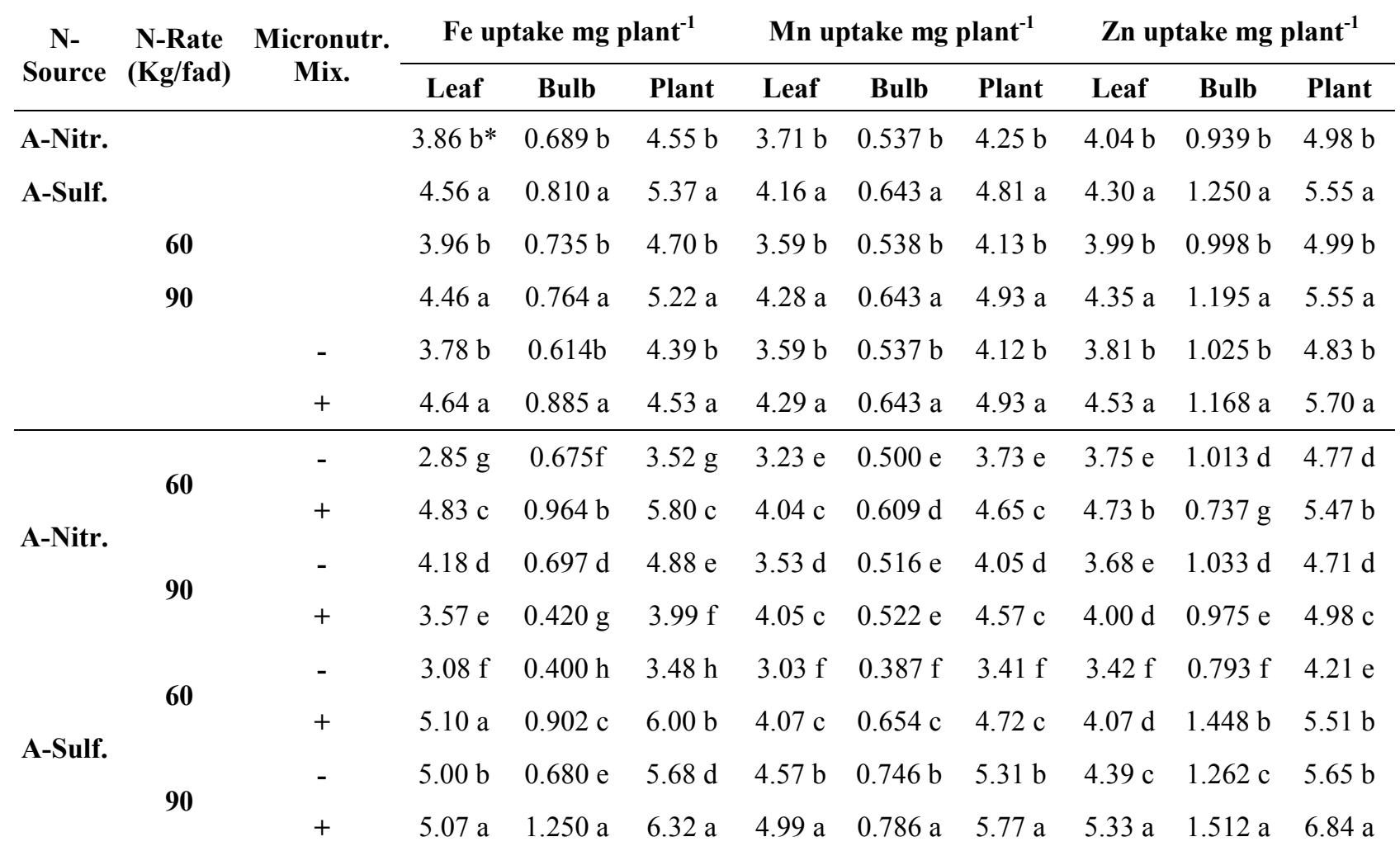

*Values followed by the same letter within a column are not significantly different at the $0.05 \%$ level of probability according to Duncan's multiple range test. A. Nitr.=Ammonium nitrate; A. Sulf.= Ammonium Sulfate; Micronutr. Mix.= Micronutrients Mixture. 
Generally, increasing nitrogen rate from 60 to 90 $\mathrm{kg} /$ fad. produced significant higher plant growth and yield of fennel cv. Florence. These results were in accordance with the previous results of Ehsanipoura et al. (2012) on fennel plants who reported that the highest seed and foliage essential oil contents and seed essential oil yield were produced at higher nitrogen level $\left(160 \mathrm{~kg}\right.$ per $\left.\mathrm{N} \mathrm{ha}^{-1}\right)$. In leafy vegetables such as lettuce, parsley and spinach, the yield increased with increasing nitrogen rate (Petropoulos et al., 2008; Konstantopoulou et al., 2010; Rop, 2012). Also, many investigators reported that increasing nitrogen levels application improved the plant growth and yield of some vegetable crops (Singer et al., 2000; Saxena et al., 2003; Hafez et al., 2004; Abdel-Mawgoud et al., 2005; Souza et al., 2008 and El-Bassiony et al., 2010). It is well known that nitrogen influences the structure and composition of photosynthetic apparatus. In crops, ribulose 1,5, bisphosphate carboxylase (rubisco) content increases linearly with leaf $\mathrm{N}$ accumulation (Kumar et al., 2002). Nitrogen fertilization management is important to optimize crop production. It is one of the most important nutrients in crop production that affect photosynthetic efficiency and leaf development, which leads to an increase in dry matter production (Dordas and Sioulas, 2008). Nitrogen is of vital importance for plant growth due to being a part of amino acid, protein, enzymes and chlorophyll molecule (Devlin and Witham, 1986).

The results of this work regarding the uptake of macro and micronutrients presented in Tables (4 and 5) showed that the uptake of macronutrients (N, P and $\mathrm{K}$ ) and micronutrients ( $\mathrm{Fe}, \mathrm{Mn}$ and $\mathrm{Zn}$ ) were at significant level in fad-fennel plants with higher nitrogen rate $(90$ $\mathrm{kg} \mathrm{N} / \mathrm{fad}$.). These results were confirmed the fact reported by Malvi (2011) who reported that optimum supply of nitrogen ensures optimum uptake of potassium as well as phosphorus, magnesium, iron, manganese and zinc from the soils that called synergism effect.

Our results concerning the effect of foliar application of micronutrients reflected enhancement effect on plant growth, yield and uptake of macro and micronutrients of fennel plants cv. Florence. In this investigation we decided to use foliar application of micronutrients instead of soil supplementation because of antagonistic effects among cations and anions may occur when fertilizers supplied together to the soil, especially in the case of alkaline soil. For example, a deficiency of $\mathrm{Zn}$ in crops is dependent on high soil $\mathrm{pH}$ (Alloway, 2008). The advantages of foliar fertilization are low application rates, uniform distribution and quick plant responses to applied nutrients (Umer et al., 1999; Mengel, 2002). Also, foliar application is a short term approach which provides more efficient utilization of nutrients and permits remediation of observed deficiencies in less time than would be done by soil application (Fageria et al., 2009). The positive effects of foliar application of micronutrients on fennel plants may be due to that the measured concentrations of $\mathrm{Fe}, \mathrm{Mn}$ and $\mathrm{Zn}$ in the tested soil were less than critical threshold, whereas the critical threshold for Fe, Mn and $\mathrm{Zn}$ are $2.5-4.5,1.2-1.4$ and $0.5-1.0 \mathrm{mg} \mathrm{kg}^{-1}$ soil.

The results in this investigation were in harmony with the results of Bhati and Srivastava (2005), Narimani et al. (2010), El-Fouly et al. (2011), Anees et al. (2011) and Yadav et al. (2013) who found that foliar application of micronutrients mixtures improved the yield and elements uptake in tomato, wheat, durum wheat, mango and peach, respectively. Iron $(\mathrm{Fe})$ is a cofactor for approximately 140 enzymes that catalyze unique biochemical reactions (Brittenham, 1994). Hence, iron fills many essential roles in plant growth and development, including chlorophyll synthesis, thylakoid synthesis and chloroplast development (Miller et al., 1995). Iron is required at several steps in the biosynthetic pathways. Foliar application of iron increased plant growth, yield and the elements uptake in dry bean (Moosavi and Ronaghi, 2010), maize (Çelik et al., 2010) and Glycine max var. Pershing (Pooladvand et al., 2013). Zinc (Zn), an essential micronutrient, plays a vital role in various processes such as carbohydrate, auxin and nucleic acid metabolism, protein synthesis (Cakmak et al., 1989), membrane stabilization and in the detoxification of highly active superoxide radicals. Zinc plays an important role as cofactors by defining the three-dimensional structure and function of many proteins as it is able to bridge many amino acid residues (Broadley et al., 2007). About $40 \%$ of the $\mathrm{Zn}$ binding proteins are thought to be transcription factors which are needed for proper gene regulation during reproductive stage development like, flower initiation (Colasanti et al., 2006), floral development (Takatsuji et al., 1992), male and female gametogenesis (Payne et al., 2004) fertilization and development and viability of seed (Sagasser et al., 2002). The previous reports dealing with foliar application of zinc to onion and mung bean plants proved that plant growth, yield and elements uptake were increased by such treatment (Trivedi and Dhumal, 2013) Manganese is involved in the oxygenevolving step of photosynthesis and membrane function, as well as serving as an important activator of numerous enzymes in the cell (Wiedenhoeft, 2006). Previous report regarding to foliar application of manganese showed that the yield of sweet orange increased significantly by Mn application (Tariq et al., 2007).

It is clear from our results that the first season of cultivation produced less yield components in comparison with the second season, this may be due to the high air temperature (from $26-32^{\circ} \mathrm{C}$ ) prevailing during earlier plant stage which affected negatively on the yield of fennel in the first season. However in the second season, the air temperature was from 8 to $11^{\circ} \mathrm{C}$ which was more suitable for normal growth of fennel plants.

In conclusion, a greater fennel plant biomass was observed when $\mathrm{N}$ fertilizer as ammonium sulphate with high rate was used. Foliar application of micronutrients mixtures improved markedly plant growth, yield and macro- and micro-nutrients uptake by different fennel plant parts. Also, results showed an evident synergism effect due to nitrogen sources $x$ nitrogen rates $x$ micronutrients mixtures, since the addition of 
micronutrients mixtures boosted plant biomass, yield and the elements uptake as $\mathrm{N}$ fertilizer rates increased and ammonium sulphate as nitrogen source was used.

\section{REFERENCES}

Abbaszadeh, B.H., S.A. Aliabadi Farahani and H. Darvishi (2009). Nitrogenous fertilizer influence on quantity and quality values of balm (Melissa officinalis L). J. Agric. Ext. Rural Dev., 1: 31-33.

Abdel-Mawgoud, A.M.R., M. EL-Desuki, S.R.Salman and S.D. Abou-Hussein (2005). Performance of some snap bean varieties as affected by different levels of mineral fertilizers. J. Agron., 4(3): 242247.

Alloway, B.J. (2008). Zinc in soils and crop nutrition. Second ed. pp 1-135, International Zinc Association and International Fertilizer Industry Association, Brussels, Belgium/Paris, France.

Anees, M., F.M. Tahir, J. Shahzad and N. Mahmood (2013). Effect of foliar application of micronutrients on the quality of mango (Mangifera indica L.) cv. Dusehri fruit. Mycopath., 9(1): 25-28.

Arabaci, O. and E. Bayram (2004). The effect of nitrogen fertilization and different plant densities on some agronomic and technologic characteristic of Ocimum basilicum L. (Basil). J. Agron., 3: 255-262.

Ashraf, M., A. Qasim, and I. Zafar (2006). Effect of nitrogen application rate on the content and composition of oil, essential oil and mineral in black cumin (Nigella sativa L.) seeds. J. Sci. Food Agric., 86: 871-876.

Assimakopoulou, A. (2006). Effect of iron supply and nitrogen form on growth, nutritional status and ferric reducing activity of spinach in nutrient solution culture. Sci. Hortic., 110: 21-29.

Ayub, M., M. Naeem, M. A. Nadeem, A. Tanveer, M. Tahir and R. Alam (2011). Effect of nitrogen application on growth, yield and oil contents of Fennel (Foenoculum vulgare Mill.). J. Medicinal Plants Res., 5(11): 2274-2277.

Bhati, L and B.K. Srivastava (2005). Effect of foliar application of micronutrients on nutrient uptake in tomato. Veg. Sci., 32(2): 158-161.

Barreyro, R., J. Ringuelet and S. Agricola (2005). Nitrogen fertilization and yield in Oregan (Origanumx applii). Cienc. Investig. Agrar., 32: 34-38.

Bremner, J.M. (1996). Total nitrogen. In: Methods of Soil Analysis, Part II, Sparks, D.L. (Ed.). SSSA Book Ser. 5. ASA and SSSA, pp. 1085-1121. Madison, WI.

Brittenham, G.M. (1994). New advances in iron metabolism, iron deficiency and iron overload. Curr. Opin. Hematol., 1: 549-556.

Broadley, M.R., P. J. White, J.P. Hammond, I. Zelko and A. Lux (2007). Zinc in plants. New Phytol., 173: 677-702.

Buntain, M., and B. Chung (1994). Effects of irrigation and nitrogen on the yield components of fennel. Aus. J. Exp. Agric., 34(6): 845-849.
Cakmak, I., H. Marschner and F. Bengerth (1989). Effect of zinc nutritional status on growth, protein metabolism and levels of indolie-3-acetic acid and other phytohormones in bean (Phaseolus vulgaris L.). J. Exp. Bot., 40: 405412.

Çelïk, H., B.B. A $\square$ ik, S. Gürel and A.V. Katkat (2010). Effect of potassium and iron on macro elements uptake of maize. Zemdirbyste-Agric., 97(1): 1122.

Chapman, H.D and P.F. Pratt (1982). Methods of analysis for soils, plants and water; Chapmann Publisher; Riverside, CA. 179 pp.

Chatzopoulou, P.S., T.V. Koutsos and S.T. Katsiotis (2006). Study of nitrogen fertilization rate on fennel cultivars for essential oil yield and composition. J. Veg. Sci., 12: 85-93.

Colasanti, J., R. Tremblay, A.Y.M. Wong, V. Coneva, A. Kozaki and B.K. Mable (2006). The maize indeterminate 1 flowering time regulator defines a highly conserved zinc finger protein family in higher plants. BMC Genomics 7: 158-175.

Devlin, R.M. and F.H. Witham (1986). Plant Physiology. $4^{\text {th }}$ ed. CBS Publishers and Distributors, 485, Jain Bhawan, Shadhara, Delhi, 110032 (India).

Dordas, C.A. and C. Sioulas (2008). Safflower yield, chlorophyll content, photosynthesis, and water use efficiency response to nitrogen fertilization under rainfad conditions. Ind. Crops. Prod., 27: 75-85.

Ehsanipour, A., J. Razmjoo and H. Zeinali (2012). Effect of nitrogen rates on yield and quality of fennel (Foeniculum vulgare Mill.) Accessions. Ind. Crops. Prod., 35: 121- 125.

El-Bassiony, A.M., Z.F. Fawzy, M.M.H. Abd El-Baky and Asmaa, R. Mahmoud (2010). Response of snap bean plants to mineral fertilizers and humic acid application. Res. J. of Agric. \& Biol. Sci., 6(2): 169-175.

El-Fouly, M.M., Z.M. Mobarak and Z. A. Salama (2011). Micronutrients (Fe, Mn, Zn) foliar spray for increasing salinity tolerance in wheat Triticum aestivum L. Afr. J. Plant Sci., 5(5): 314322.

Elwan, M.W.M. and K.E. Abd El-Hamed (2011). Influence of nitrogen form, growing season and sulfur fertilization on yield and the content of nitrate and vitamin $\mathrm{C}$ of broccoli. Sci. Hortic., 127: $181-187$

Fageria, N.K., A.B. Dos Santos and M.F. Moraes (2010). Influence of urea and ammonium sulfate on soil acidity indices in lowland rice production. Commun. Soil Sci. Plant Anal., 41:1565-1575.

Fageria, N.K., M.P.B. Filhoa, A. Moreirab and C.M. Guimaresa (2009). Foliar fertilization of crop plants. J. Plant Nutr., 32: 1044-1064.

Gee, G.W. and J.W. Bauder (1986). Particle-size analysis. In Methods of soil analysis, ed. A. Klute, pp. 383-409. Madison, Wisc.: ASA and SSSA.

Güelser, F. (2005). Effects of ammonium sulphate and urea on $\mathrm{NO}_{3}^{-}$and $\mathrm{NO}_{2}^{-}$accumulation, nutrient 
contents and yield criteria in spinach. Sci. Hortic., 106: 330-340.

Hafez, M. Magda and Asmaa R. Mahmoud (2004). Response of snap bean (Phaseolus vulgaris L.) to nitrogen fertilizer source. Ann. Agric. Sci. Mashtohor, 42(1): 261270.

Hussain, M.A. and M.M. Abou El-Magd (1993). Effect of nitrogenous fertilization on growth, vegetative yield, seed and oil content of sweet fennel (Foeniculum vulgare var. dulce) Afr. J. Agric. Sci., 18: 135-143.

Jabbari, R., M.A. Dehaghi, A.M. Modares Sanavi and K. Agahi (2011). Nitrogen and iron fertilization methods affecting essential oil and chemical composition of Thyme (Thymus Vulgaris L.) medical plant. Adv. Environ. Biol., 5(2): 433438.

Jackson, M.L. (1967). Soil Chemical Analysis. Prentice Hall Inc., Englewood Cliffs, N.J., Library of Congress, USA.

Kandil A.M., S.A.T. Naglaa and A.A. Sadek (2002). Effect of biofertilizers on the growth, volatile oil yield and chemical composition of Ocimum basilicum L. plant. Ann. Agric. Sci., Ain Shams Univ., Cairo, 47(1): 351-371.

Klocke, N.L. and P.E. Fischbach (1984). Estimating Soil Moisture by Appearance and Feel. University of Nebraska-Lincoln Extension. G84690.

Konstantopoulou, E., G. Kapotis, G. Salachas, S.A. Petropoulos, I.C. Karapanos and H.C. Passam (2010). Nutritional quality of greenhouse lettuce at harvest and after storage in relation to $\mathrm{N}$ application and cultivation season. Sci. Hortic., 125: 93.e1-93.e5.

Kumar, P.A., M.A.J. Parry, R.A.C. Mitchell, A. Ahmad and Y.P. Abrol (2002). Photosynthesis and nitrogen use efficiency. In: Foyer $\mathrm{CH}$, Noctor $\mathrm{G}$, editors. Photosynthetic nitrogen assimilation and associated carbon and respiratory metabolism: advances in photosynthesis and respiration. Dordrecht: pp. 23-34, Springer.

Kuo, S. (1996). Phosphorus. In: Methods of Soil Analysis, Part III Chemical Methods. Sparks, D. L. (Ed.). SSSA, Madison, WI., PP. 869-919.

Ling, E.R. (1963). Determination of total nitrogen by semi micro kjeldahl method. Dairy Chem., 11: 23-84.

Malvi, U. (2011). Interaction of micronutrients with major nutrients with special reference to potassium. Karnataka J. Agric. Sci., 24 (1): 106109.

Marschner, H. (1995). Mineral nutrition of higher plants. Second Ed., Academic Press Limited. Harcourt Brace and Company, Publishers, London. Pp. 1-681

Mengel, K. (2002). Alternative or complementary role of foliar supply in mineral nutrition. Acta. Hortic., 594: 33-47.

Miles, D.L. and I. Broner (1998). IRRIGATION, Estimating Soil Moisture. Colorado State University Extension Crop Series. No. 4.700.
Miller, N.J., A.T. Diplock and C.A. Rice-Evans (1995). Evaluation of the total antioxidant activity as a marker of the deterioration of apple juice in storage. J. Agric. Food Chem., 43: 1794-1801.

Moosavi, A.A. and A. Ronaghi (2013). Growth and iron-manganese relationships in dry bean as affected by foliar and soil applications of iron and manganese in a calcareous soil. J. Plant Nutr., 9(33): 1353-1365.

Narimani1, H., M.M. Rahimi, A. Ahmadikhah and B. Vaezi (2010). Study on the effects of foliar spray of micronutrient on yield and yield components of durum wheat. Arch. Applied Sci. Res., 2 (6):168-176.

Ozguven, M., F. Ayanglu and A. Ozel (2006). Effect of nitrogen rates and cutting times on the essential oil yield and components of Origanum syriacum L. var. Bevanii. J. Agron., 5: 1010-1105.

Page, A.L., R.H. Miller and D.R. Keeney (1982). Methods of Soil Analysis. Part 2: Chemical and Microbiological Properties. ASA, Madison, WI.

Payne, T., S.D. Johnson and A.M. Koltunow (2004). KNUCKLES (KNU) encodes a $\mathrm{C}_{2} \mathrm{H}_{2}$ zinc-finger protein that regulates development of basal pattern elements of the Arabidopsis gynoecium. Development, 131: 3737-3749.

Petropoulos, S.A., C.M. Olympios and H.C. Passam (2008). The effect of nitrogen fertilization on plant growth and the nitrate content of leaves and roots of parsley in the Mediterranean region. Sci. Hortic., 118: 255-259.

Pooladvand, S., M. Ghorbanli and M.F. Sepehr (2013). Effect of various levels of iron on morphological, biochemical, and physiological properties of Glycine max var. Pershing. Iran. J. Plant Physiol., 2(4): 531-538.

Richards, L.A. (1954). Diagnosis and Improvement of Saline and Alkali Soils. US Salinity Lab., US Department of Agriculture Handbook 60 . California, USA.

Rop, N.K., T.M. Mutui and E.K. Kiprop (2012). Influence of nitrogen fertilizer on the growth, yield and quality of Indian spinach (Basella alba L.). Afr. J. Hort. Sci., 6:111-117.

Sagasser, M., G. H. Lu, K. Hahlbrock and B. Weisshaar (2002). A. thaliana TRANSPARENT TESTA 1 in involved in seed coat development and defines the WIP subfamily of plants zinc finger proteins. Genes Dev., 16, 138-149.

Said-Al Ahl, H.A.H. and A.A. Mahmoud (2011). Effect of zinc and / or iron foliar application on growth and essential oil of sweet basil (Ocimum basilicum L.) under salt stress. Ozean J. Appl. Sci., 3(1): 97-111.

Sanjuan N., G. Clemente and L. Ubeda (2003). Environmental effect of fertilizers. In: Dris, R., R. Niskanen and M.S. Jain (eds.). Crop Management and Post-harvest Handling of Horticultural Products: Crop Fertilization, Nutrition and Growth. Enfield, USA: Science Publishers, Inc: pp. 1-53. 
Santamaria, P. and A. Elia (1997). Producing nitratefree endive heads: effect of nitrogen form on growth, yield and ion composition of endive. J. Am. Soc. Hortic. Sci., 122: 140-145.

Saxena, K.K. Arun-Srivastava and R.B. Singh (2003). Response of French bean to nutrient application (NPK) in relation to physiological traits and their consequent effect on yield. Farm Sci. J., 12(2): 150-152.

Simonne, E., A. Simonne and L. Wells (2001). Nitrogen source affects crunchiness, but not lettuce yield. J. Plant Nutr., 24: 743-751.

Singer, S.M., A.H. Ali, M. EL-Desuki, A.M. Gomaa and M.A. Khalafallah (2000). Synergistic effect of bio and chemical fertilizers to improve quality and yield of snap bean grown in sandy soil. Acta Hort., 513: 213-220.

Sotiropoulou, D.E. and A.J. Karamanos (2010). Field studies of nitrogen application on growth and yield of Greek Oregano (Origanum vulgare ssp. hirtum (Link) letsweert). Ind.. Crops. Prod., 29: $10-15$.

Souza, A.B.De., M.J.B. De. Andrade, N.M.B. Vieira and A. De. Albuquerque (2008). Sowing densities and NPK and liming levels on common bean yield, in conventional cropping system, in Ponta Grossa, Parana State, Brazil. Pesq Agropec Trop, 38(1): 39-43.

Sparks, D.L., A.L. Page, P.A. Helmke, R.H. Loeppert, P. N Soltanpour, M.A. Tabatabai, C.T. Johnston, and M.E. Sumner (1996). Methods of soil analysis. Madison, Wisc.: ASA and SSSA.

Statsoft, Inc. (2001). STATISTICA fuer Windous [Software-system fuer Datenanalyse] Version 6. www.Statsoft.com.

Takatsuji, H., M. Mori, P.N. Benfey, L. Ren and N.H. Chua (1992). Characterization of zinc finger
DNA-binding protein expressed specifically in petunia petals and seedlings. EMBO J., 11: 241249.

Tariq, M, M. Sharif, Z. Shah and R. Khan (2007). Effect of foliar application of micronutrients on the yield and quality of sweet orange (Citrus sinensis L.). Pak. J. Biol. Sci., 10(11): 1823-1828.

Tisdale, S.L. and W.L. Nelson (1990). Soil fertility and effect of magnesium sources on the yield and chemical composition of crops. Michigan Agricultural Experimental Station, pp. 29-31. Bull press, Michigan, America,

Trivedi, A.P. and K.N. Dhumal (2013). Effect of soil and foliar applications of zinc and iron on the yield and quality of onion (Allium cepa L..). Bangladesh J. Agril. Res., 38(1): 41-48.

Umer, S., S.K. Bansal, P. Imas and H. Magen (1999). Effect of foliar fertilization of potassium on yield, quality and nutrient uptake of groundnut. J. Plant Nutr., 22: 1785-1795.

Wang, X.F. and I. Tadashi (1997). Effect of $\mathrm{NO}_{3}-\mathrm{N}$ in the additional nutrient solution on the growth, yield, and NO3 content in spinach plant grown in hydroponics. J. Jpn. Soc. Hortic. Sci., 66:313-319.

Wang, Z. and S. Li (2004). Effects of nitrogen and phosphorus fertilization on plant growth and nitrate accumulation in vegetables. J. Plant. Nutr., 27: 539-556.

Wiedenhoeft, A.C. (2006). Micronutrients. In Plant Nutrition, ed., W.G. Hapkins, pp. 14-36. Chelsea House Publications.

Yadav, V., P.N. Singh and P. Yadav (2013). Effect of foliar fertilization of boron, zinc and iron on fruit growth and yield of low-chill peach cv. Sharbati. Int. J. Sci Res. Pub., 3 (8): 1-6.

\section{تحسين النمو والمحصول في نبات الفينوكيا باستخذام مصادر ومستويات من الأسمدة النيتروجينية والرش الفر بمخلوط العناصر الصغرى مئر}

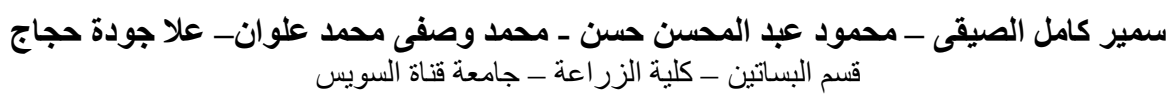

أجريت هذه الدر اسة بهدف إعطاء بعض المعلومات و التي من الممكن أن تحسن من الحالة الغذائية و إنتاجية الفينوكيا. حيث تم در اسة

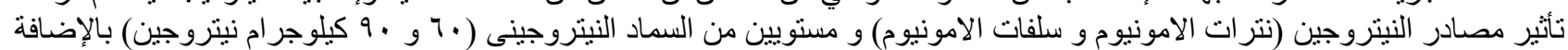

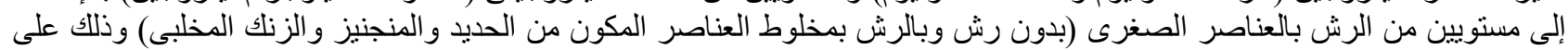

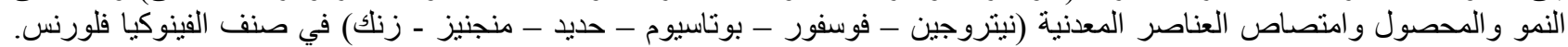

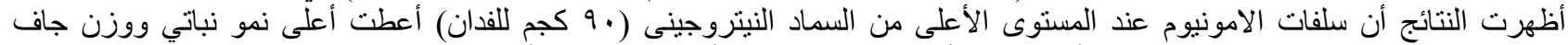

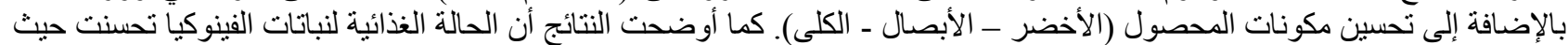

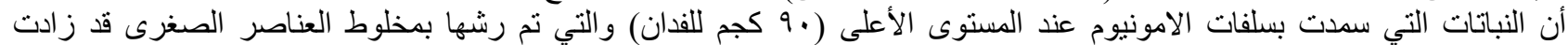

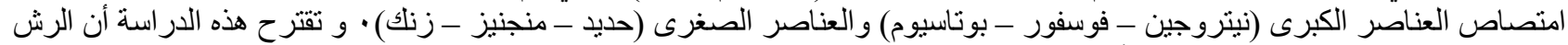

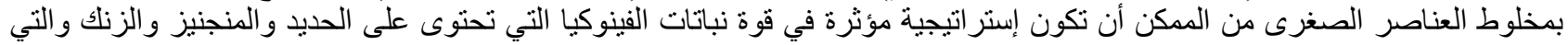
تؤدى إلى إنتاج محصول ذو جودة غذائية عالية. 